\title{
In vitro and in vivo anti-inflammatory activities of a sterol-enriched fraction from freshwater green alga, Spirogyra sp.
}

Lei Wang ${ }^{1,2}$, You-Jin Jeon ${ }^{1,2}$ and Jae-II Kim ${ }^{3^{*}}$ (D)

\begin{abstract}
Background: Inflammation plays a crucial role in the pathogenesis of many diseases such as arthritis and atherosclerosis. In the present study, we evaluated anti-inflammatory activity of sterol-rich fraction prepared from Spirogyra sp., a freshwater green alga, in an effort to find bioactive extracts derived from natural sources.

Methods: The sterol content of ethanol extract of Spirogyra sp. (SPE) was enriched by fractionation with hexane (SPEH), resulting 6.7 times higher than SPE. Using this fraction, the in vitro and in vivo anti-inflammatory activities were evaluated in lipopolysaccharides (LPS)-stimulated RAW 264.7 cells and zebrafish.

Results: SPEH effectively and dose-dependently decreased the production of nitric oxide (NO) and prostaglandin $\mathrm{E}_{2}$ $\left(\mathrm{PGE}_{2}\right)$. SPEH suppressed the production of pro-inflammatory cytokines including interleukin-6 (IL-6), tumor necrosis factor-a (TNF-a), and IL-1 $\beta$ through downregulating nitric oxide synthase (iNOS) and cyclooxygenase-2 (COX-2) expression in LPS-stimulated RAW 264.7 cells without cytotoxicity. The in vivo test results indicated that SPEH significantly and dose-dependently reduced reactive oxygen species (ROS) generation, cell death, and NO production in LPS-stimulated zebrafish.

Conclusions: These results demonstrate that SPEH possesses strong in vitro and in vivo anti-inflammatory activities and has the potential to be used as healthcare or pharmaceutical material for the treatment of inflammatory diseases.
\end{abstract}

Keywords: Spirogyra sp., Sterol-enriched fraction, Anti-inflammatory activity, RAW 264.7 cells, Zebrafish

\section{Background}

Inflammation is a highly regulated biological process that enables the immune system to efficiently eliminate stimuli and injuries (Masresha et al. 2012). Inflammation can be classified into two subtypes, chronic and acute inflammation, depending on the difference in response time and procedure. Acute inflammation is an initial response of bodies against harmful stimuli. During acute inflammatory response, the plasma and leukocytes are moving from the blood into the injured tissues. There is a shift in the type of mononuclear phagocytic cells in the

\footnotetext{
* Correspondence: jikim@pknu.ac.kr

${ }^{3}$ Department of Food Science and Nutrition, Pukyong National University, Busan 48513, Republic of Korea

Full list of author information is available at the end of the article
}

inflammatory tissues during the course of inflammatory response, from pro-inflammatory to anti-inflammatory or wound healing type.

The inflammatory response is associated with the release of the inflammatory mediators, including nitric oxide (NO), prostaglandins, histamine, and bradykinin from various immune cells such as mononuclear phagocytes and mast cells (González Mosquera et al. 2011; Wijesinghe et al. 2014a). Inflammation is crucial in many diseases such as arthritis, atherosclerosis, cancer, and some deadly diseases (Lee and Weinblatt 2001; Firestein 2006; Klegeris et al. 2007; Wen et al. 2016; Wijesinghe et al. 2013; Wijesinghe et al. 2014b). Therefore, there is increasing attention on finding safe and effective anti-

(c) The Author(s). 2020 Open Access This article is licensed under a Creative Commons Attribution 4.0 International License, which permits use, sharing, adaptation, distribution and reproduction in any medium or format, as long as you give appropriate credit to the original author(s) and the source, provide a link to the Creative Commons licence, and indicate if changes were made. The images or other third party material in this article are included in the article's Creative Commons licence, unless indicated otherwise in a credit line to the material. If material is not included in the article's Creative Commons licence and your intended use is not permitted by statutory regulation or exceeds the permitted use, you will need to obtain permission directly from the copyright holder. To view a copy of this licence, visit http://creativecommons.org/licenses/by/4.0/ 
inflammatory agents and elucidating their antiinflammatory mechanisms.

Algae are considered as a potential bio-resource for the development of functional food, cosmeceutical, and pharmaceutical because they are rich in various bioactive compounds, such as proteins, polysaccharides, phenolic compounds, and sterols (Kim et al. 2016; Sanjeewa et al. 2016; Fernando et al. 2017b). These compounds possess broad-spectrum bioactivities including anti-bacterial, anti-inflammatory, antioxidant, and anti-cancer activities (Jung et al. 2008; Heo et al. 2010; Lee et al. 2012; Lee et al. 2013; Oh et al. 2016; Fernando et al. 2017a).

Spirogyra sp. is freshwater green alga. It has been used as a bio-sorbent to remove heavy metal ions from wastewater (Khalaf 2008). Recently, the pharmacological activities of Spirogyra sp, such as antioxidant, ultraviolet (UV)-protective, and anti-hypertension activities, have been reported (Kang et al. 2015; Lee et al. 2016; Wang et al. 2017). However, the anti-inflammatory activities of Spirogyra sp. have not been evaluated so far. Therefore, in the present study, ethanol extract of Spirogyra sp. (SPE) and the fractions from SPE were prepared, and their antiinflammatory activities were evaluated in lipopolysaccharides (LPS)-stimulated RAW264.7 cells. The effect of sterol-enriched fraction (SPEH) from SPE on the production of pro-inflammatory mediators was investigated by enzyme-linked immunosorbent assay (ELISA) and western blot analysis. In addition, the in vivo anti-inflammatory effect of SPEH was evaluated using a zebrafish model.

\section{Methods}

\section{Chemicals and regents}

LPS, acridine orange, $2^{\prime}, 7^{\prime}$-dichlorofluorescin diacetate $\left(\mathrm{DCFH}_{2}-\mathrm{DA}\right)$, dimethyl sulfoxide (DMSO), and diaminofluorescein-FM diacetate (DAF-FM DA) were purchased from Sigma-Aldrich (St. Louis, MO, USA). Fetal bovine serum (FBS), penicillin-streptomycin (P/S), and Dulbecco's modified Eagle's medium (DMEM) were purchased from Gibco/BRL (Grand Island, NY, USA). The ELISA kits for measuring prostaglandin $\mathrm{E}_{2}\left(\mathrm{PGE}_{2}\right)$,

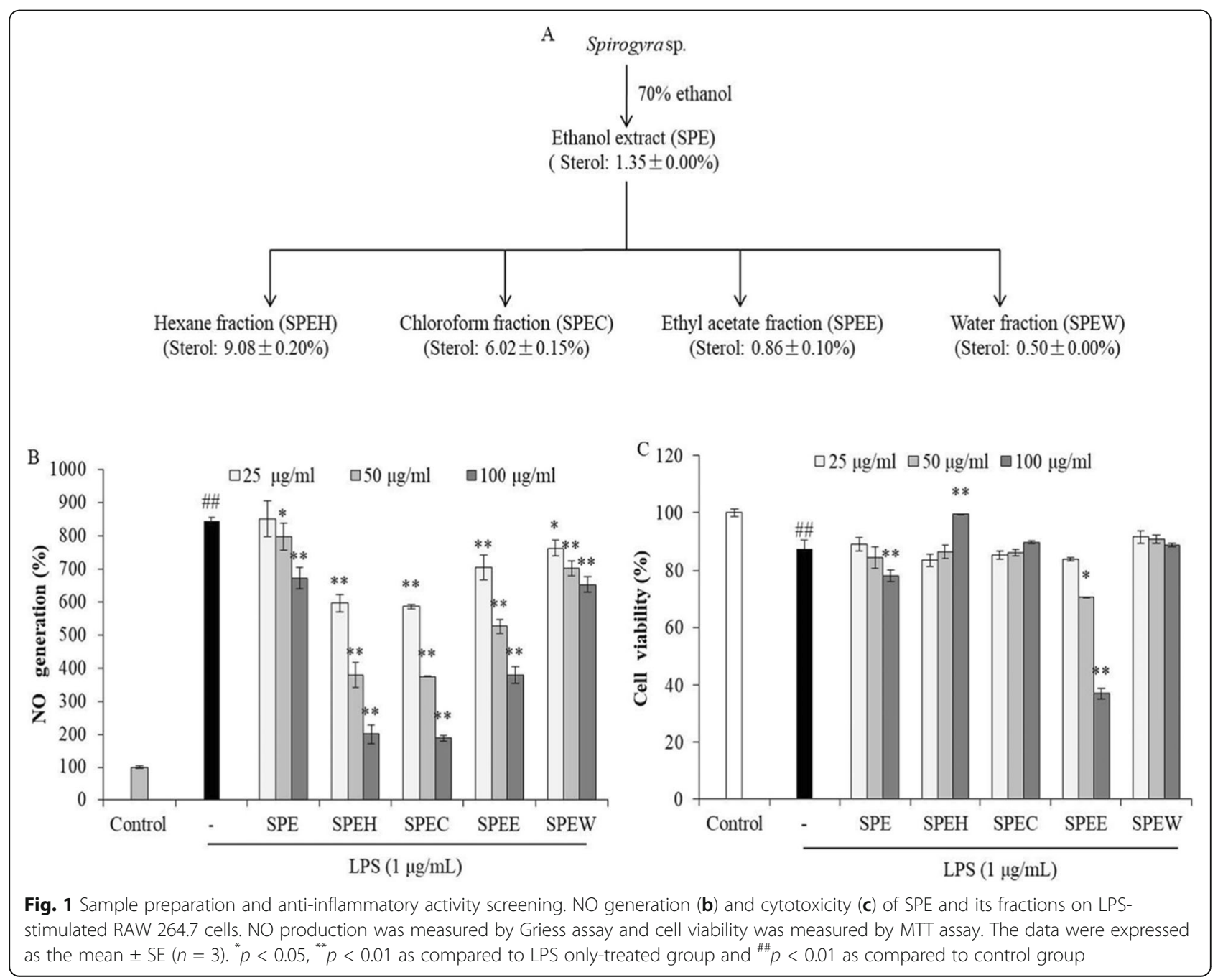


interleukin-6 (IL-6), tumor necrosis factor- $\alpha$ (TNF- $\alpha$ ), and IL-1 $\beta$ levels were purchased from R\&D Systems Inc. (Minneapolis, MN, USA). Antibodies against $\beta$-actin, cyclooxygenase-2 (COX-2), and inducible nitric oxide synthase (iNOS) were purchased from Santa Cruz Biotechnology (Santa Cruz, CA, USA). Secondary antirabbit and anti-mouse IgG antibodies were purchased from Cell Signaling Technology (Beverly, MA, USA). Other chemicals and regents used in the present study were analytical grade.

\section{Extraction and fractionation}

Sampling, processing, extraction, and fractionation were performed following the protocols described in the previous study (Wang et al. 2017). In brief, lyophilized Spirogyra sp. powder was extracted by $70 \%$ ethanol; the $70 \%$ ethanol extract of Spirogyra sp. (SPE) was fractionated by hexane, chloroform, and ethyl acetate, respectively. Then, the hexane (SPEH), chloroform (SPEC), ethyl acetate (SPEE), and water (SPEW) fractions of SPE were obtained. Samples were concentrated and stored at $-20{ }^{\circ} \mathrm{C}$ until used.

\section{Sterol content analysis}

The sterol contents of samples were measured by Liebermann Burchard method described by Xiong et al. (2007). In brief, the samples (2 mg) were dissolved in glacial acetic acid $(1 \mathrm{~mL})$ and mixed with prepared Liebermann Burchard regent. The mixture was reacted in the dark at the room temperature for $10 \mathrm{~min}$. After reaction, the absorbance of the mixture was recorded at 625 nm using a micro-plate reader (BioTek, Synergy, HT, USA). Cholesterol was used as standard sterol compound to prepare the standard curve.

\section{Cell culture}

RAW 264.7 cells (ATCC $^{\oplus}$ TIB-71 $1^{\text {mat }}$ ) were cultured in DMEM containing FBS (10\%) and P/S (1\%) under a humidified atmosphere containing $5 \% \mathrm{CO}_{2}$ at $37{ }^{\circ} \mathrm{C}$. RAW 264.7 cells were seeded as a density of $1 \times 10^{5}$ cells $/ \mathrm{mL}$ for experiments.

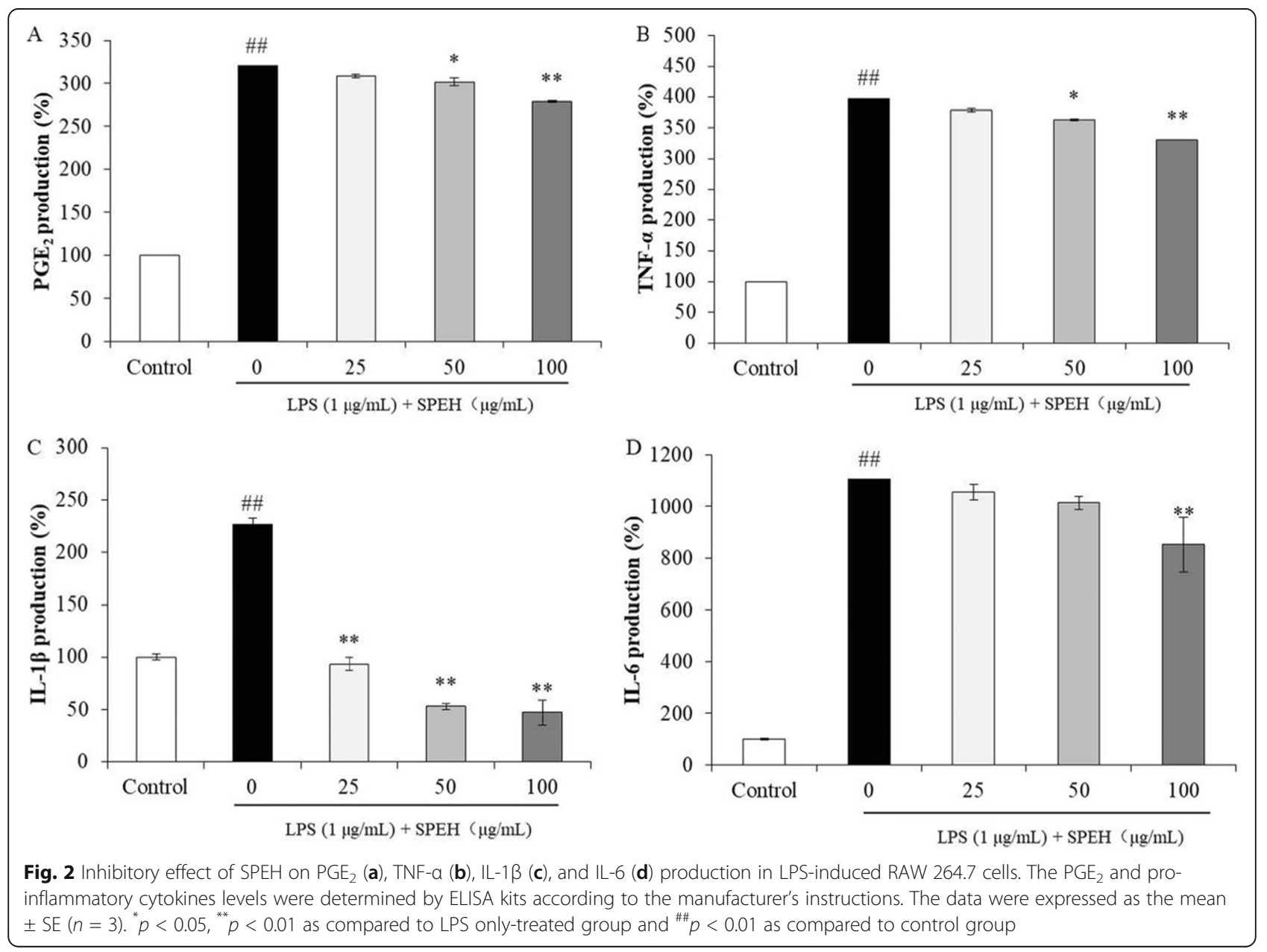


Determination of NO, pro-inflammatory cytokines, $\mathrm{PGE}_{2}$ production, and cell viability

RAW 264.7 cells were seeded and incubated for $24 \mathrm{~h}$. Cells were treated with different concentrations of samples and incubated for $1 \mathrm{~h}$. After incubation, LPS $(1 \mu \mathrm{g} /$ $\mathrm{mL}$ ) was introduced to cells. The culture medium was collected and used for measuring NO, PGE 2 , TNF- $\alpha$, IL6 , and IL- $1 \beta$ production levels. The NO production levels of LPS-treated RAW264.7 cells were measured using Griess reagent. The PGE 2 , TNF- $\alpha$, IL- 6 , and IL- $1 \beta$ production levels were evaluated using the commercial ELISA kits following the manufacturer's instructions. The cell viability was measured by MTT assay based on the method described by Wang et al. (2018).

\section{Western blot analysis}

The LPS-stimulated RAW 264.7 cells were harvested and lysed. The lysates contain $50 \mu \mathrm{g}$ of protein were subjected to electrophoresis on SDS-polyacrylamide gels $(12 \%)$. Then, the proteins were transferred onto nitrocellulose membranes, and the membranes were incubated with the primary antibodies at $4{ }^{\circ} \mathrm{C}$. After $6 \mathrm{~h}$ incubation, the membranes were incubated with HRPconjugated secondary antibody and visualized using ECL reagent (Amersham, Arlington Heights, IL, USA).

\section{Measurement of survival rate and heart-beating rate on LPS-stimulated zebrafish}

Approximately 7-9 h post-fertilization (hpf), zebrafish embryos (15 embryos/group) were treated with different concentrations of SPEH for $1 \mathrm{~h}$. Then, LPS $(10 \mu \mathrm{g} / \mathrm{mL})$ was added into the embryo medium. The survival rate was measured at 3 days post-fertilization (dpf) by counting live embryos, and heart-beating rate was measured following the protocol described by Sanjeewa et al. (2018).

Measurement of reactive oxygens species (ROS) generation, cell death, and NO production on LPSstimulated zebrafish

At $3 \mathrm{dpf}$, zebrafish were dyed with $\mathrm{DCFH}_{2}$-DA $(20 \mu \mathrm{g} /$ $\mathrm{mL})$, acridine orange $(7 \mu \mathrm{g} / \mathrm{mL})$, and DAF-FM-DA

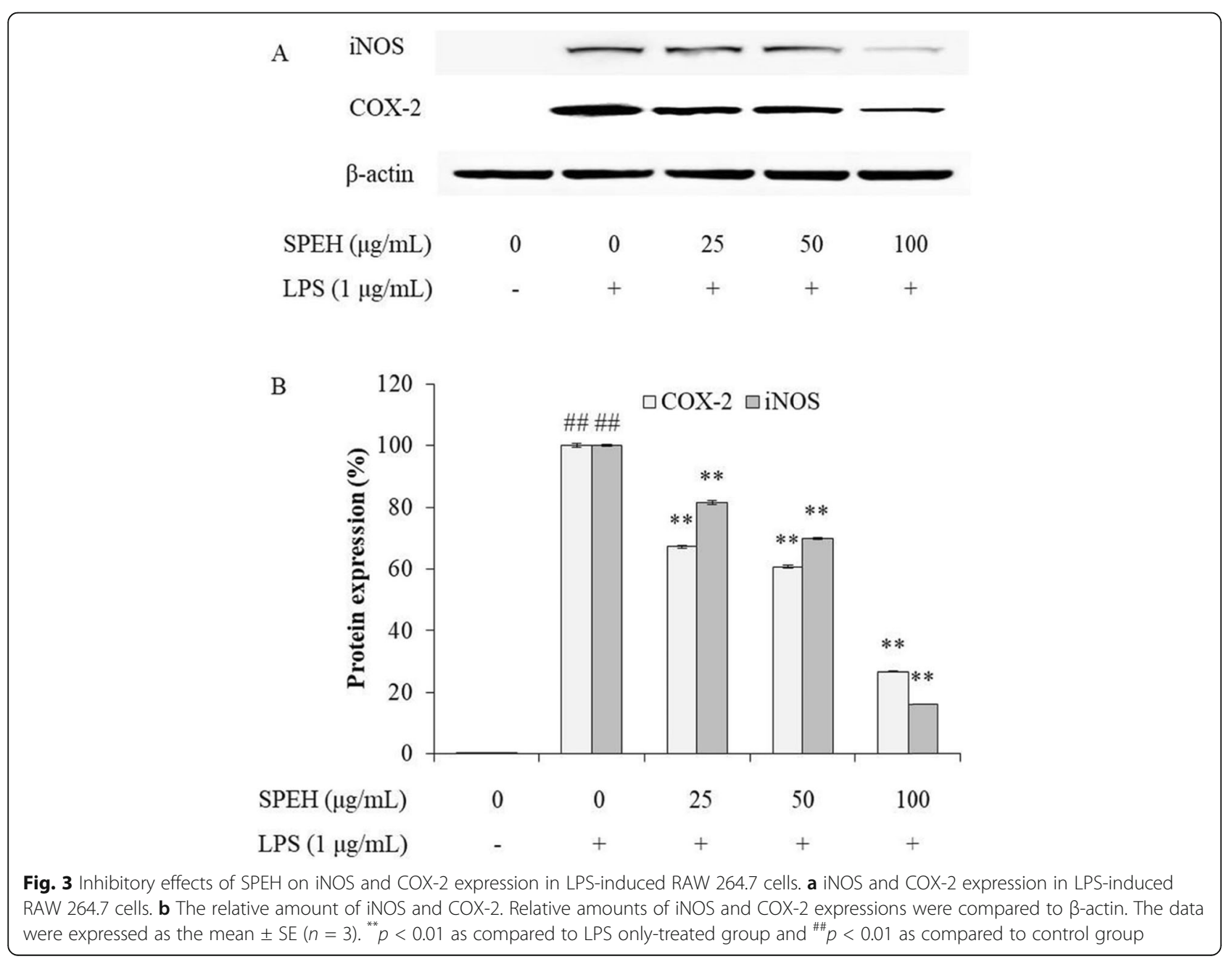


solutions $(5 \mu \mathrm{M})$ for the detection of ROS generation, cell death, and NO production, respectively. The anesthetized zebrafish were photographed under the microscope equipped with Cool SNAP-Procolor digital camera (Olympus, Japan). The fluorescence intensity of individual zebrafish was quantified using an Image J program.

\section{Statistical analysis}

The data were expressed as the mean \pm standard error (SE). One-way ANOVA test (using SPSS 11.5 statistical software) was used to compare the mean values of each treatment. The significant differences were established as $* p<0.05, * * p<0.01$ as compared to LPS only-treated group and ${ }^{\# \#} p<0.01$ as compared to control group.

\section{Results and discussion}

Sterol content of SPE and its fractions

Algae-derived compounds possess various health benefits (Mayer and Hamann 2003; Athukorala and Jeon 2005; Heo et al. 2005; Kotake-Nara et al. 2005). The sterols including cholesterol, $\beta$-sitosterol, campesterol, and polyhydroxylated sterols isolated from algae were shown to strong bioactivities, especially anticancer and anti-inflammatory activities (Kazłowska et al. 2013; Elbagory et al. 2015). The freshwater green alga, Spirogyra sp. contains various bioactive compounds. In our previous studies, we have reported antioxidant, UVB photoprotective, and anti-hypertension activities of phenolic compounds isolated from Spirogyra sp. (Kang et al. 2015; Wang et al. 2017). However, the bioactivities of sterols from Spirogyra sp. have not been evaluated yet. In the present study, we have prepared a sterol-enriched fraction (SPEH) from Spirogyra sp. and evaluated its in vitro and in vivo anti-inflammatory activities.

As shown in Fig. 1, the sterol contents of SPE and its fractions were ranged from $0.50 \%$ to $9.08 \%$. This result indicates that the sterol content in hexane fraction (SPEH) was enriched with 6.7 times than SPE. Many reports support sterols isolated from algae possess strong anti-inflammation activity (Ku et al. 2013; Sanjeewa
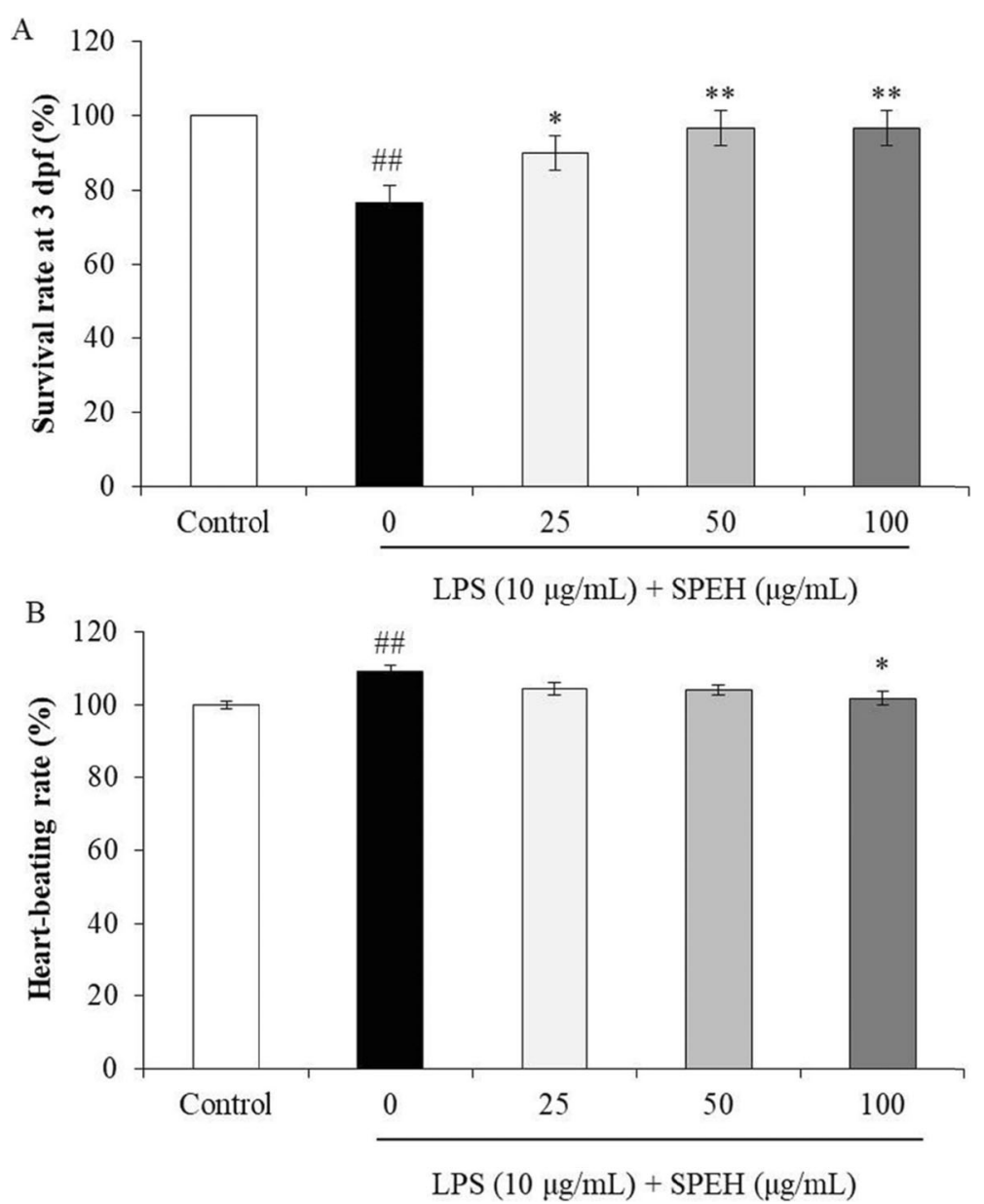

Fig. 4 SPEH improved the survival rate and reduced heart-beating rate in LPS-stimulated zebrafish. a The survival rate. $\mathbf{b}$ the heart-beating rate. The data were expressed as the mean \pm SE $(n=3) .^{*} p<0.05$, and ${ }^{* *} p<0.01$ as compared to LPS only-treated group and ${ }^{\# \#} p<0.01$ as compared to control group. 
et al. 2016; Suh et al. 2018). Our previous study investigated anti-cancer and anti-inflammatory activities of the sterol-rich fraction of Nannochloropsis oculata. The results indicated that the hexane fraction of methanol extract of $N$. oculata is rich in sterol content and possesses strong anti-inflammatory activity. In this regard, antiinflammatory activity can be expected from SPEH prepared in this study, in which the content of sterol was $9.08 \%$.

\section{In vitro anti-inflammatory effect of SPEH}

In order to evaluate the anti-inflammatory activity of SPE and its fractions, their inhibitory effects on NO production were measured. As shown in Fig. 1, all samples significantly and dose-dependently decreased NO production (Fig. 1b). However, SPE and SPEE showed remarkable cytotoxicity in RAW264.7 cells. SPEH and SPEC that contain relative higher sterol contents showed stronger NO inhibitory effect in LPS-induced RAW264.7 cells than other samples. Furthermore, SPEH significantly improved the viability of LPS-induced RAW264.7 cells at high concentration. The viability of the cells treated with $100 \mu \mathrm{g} / \mathrm{mL}$ of SPEH was $99.52 \%$, which is close to the cells not treated with LPS (100\%) (Fig. 1c). These results indicate that $\mathrm{SPEH}$ showed the most potent anti-inflammatory activity among 5 samples. Thus, SPEH was selected as the target sample for the further study.

We next examined the inhibitory effects of SPEH on the production of $\mathrm{PGE}_{2}$ and pro-inflammatory cytokines in LPS-stimulated RAW264.7 cells. As Fig. 2a shows, LPS induced PGE 2 level in RAW264.7 cells to $319.85 \%$ compared to the control group (100\%). However, the $\mathrm{PGE}_{2}$ levels of LPS-treated cells were decreased to $307.83 \%, 301.38 \%$, and $278.90 \%$ by 25,50 , and $100 \mu \mathrm{g} /$ $\mathrm{mL}$ of SPEH treatment, respectively. In addition, SPEH inhibited $17.70 \%, 33.01 \%$, and $65.76 \%$ of TNF- $\alpha$ (Fig. $2 b), 113.31 \%, 173.91 \%$, and $179.67 \%$ of IL-1 $\beta$ (Fig. 2c), $50.233 \%, 91.22 \%$, and $252.14 \%$ of IL- 6 expressions (Fig. $2 \mathrm{~d})$ at the concentration of 25,50 , and $100 \mu \mathrm{g} / \mathrm{mL}$, respectively.

iNOS and COX-2 are two inducible enzymes, which synthesize two key inflammatory mediators, NO and $\mathrm{PGE}_{2}$, respectively (Kim et al. 2005; Wijesinghe et al.

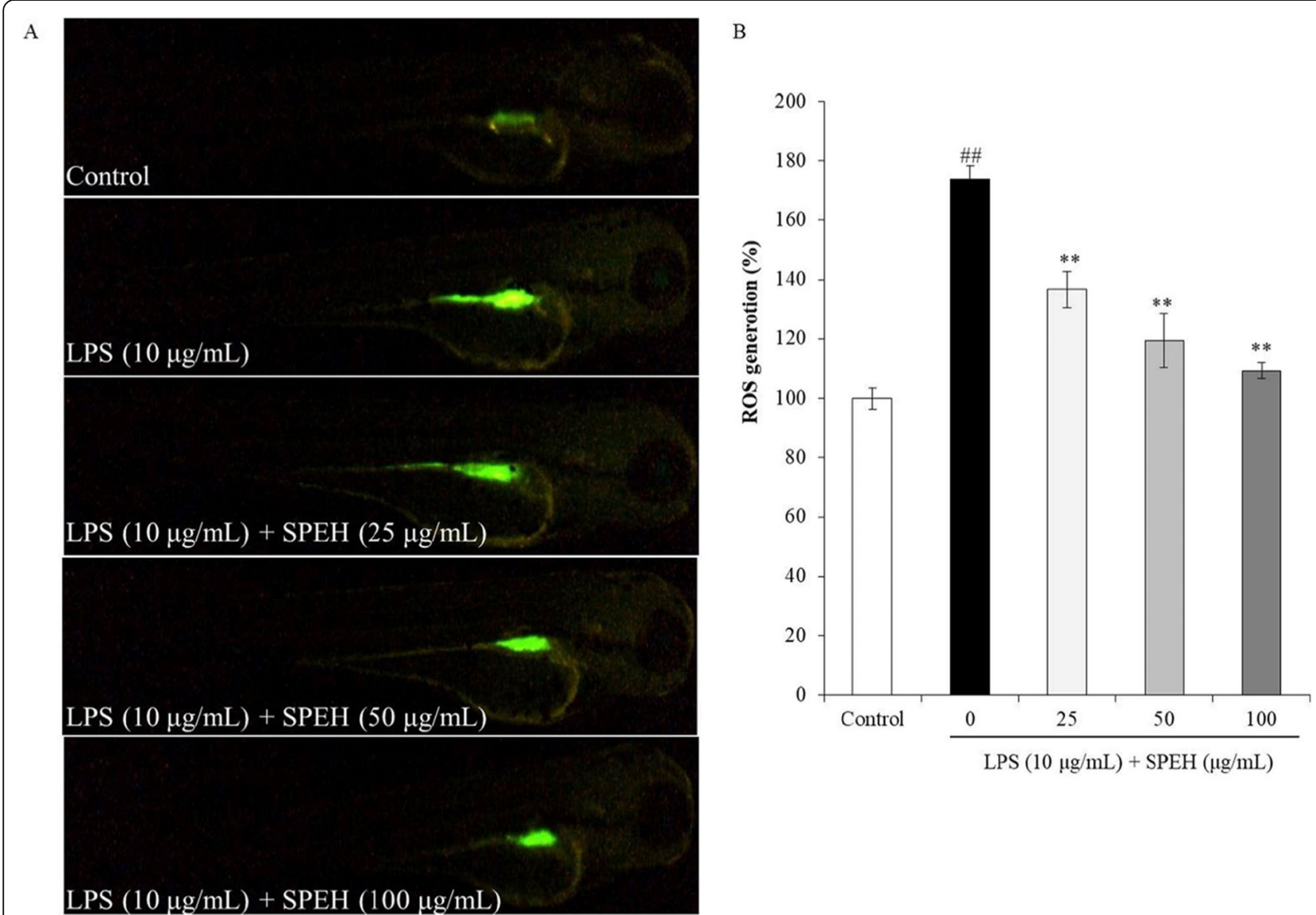

Fig. 5 The protective effect of SPEH against LPS-induced ROS generation in zebrafish. a Zebrafish under fluorescence microscope. b The levels of ROS. ROS levels were measured using Image J software. The data were expressed as the mean \pm SE $(n=3) .{ }^{* *} p<0.01$ as compared to LPS onlytreated group and ${ }^{\# \#} p<0.01$ as compared to control group 
2014a). The levels of iNOS and COX-2 are up-regulated in inflammatory response (Wijesinghe et al. 2014a; Wijesinghe et al. 2014b; Xiong et al. 2014). Therefore, we investigated the effect of SPEH on the protein expression levels of iNOS and COX-2 in LPS-stimulated RAW 264.7 cells. As shown in Fig. 3, LPS significantly stimulated iNOS and COX-2 expressions, but SPEH remarkably and dose-dependently downregulated the expression level of iNOS and COX-2. These results indicated that SPEH possesses strong in vitro antiinflammatory activity.

\section{In vivo anti-inflammatory effect of SPEH}

In vivo evaluation for anti-inflammation activity of SPEH was adopted in zebrafish due to its advantages such as similarity to mammals, short life span, and the ability of the female fish to produce a large number of eggs (Kishi et al. 2003; Ko et al. 2011). In the present study, we investigated the survival rate, heart-beating rate, ROS generation, cell death, and NO generation in zebrafish. As shown in Fig. 4a, while the survival rate of zebrafish was significantly reduced by LPS, it was remarkably and dose-dependently increased by SPEH-treatment. In addition, the heart-beating rate of LPS-treated zebrafish was significantly increased (112.93\%) compared to nontreated zebrafish (100\%) (Fig. 4b). However, it was restored to the normal level in the zebrafish treated with $100 \mu \mathrm{g} / \mathrm{mL}$ of SPEH (101.65\%) (Fig. 4b). The ROS generation and cell death levels of SPEH-treated zebrafish were significantly and dose-dependently reduced compared to the zebrafish treated with LPS only (Figs. 5 and 6). Furthermore, SPEH pretreatment reduced 26.04, 39.08 , and $50.88 \%$ of NO production in LPS-stimulated zebrafish pretreated with 25,50 , and $100 \mu \mathrm{g} / \mathrm{mL}$, respectively (Fig. 7). These results indicated that SPEH possesses strong in vivo anti-inflammatory activity.

\section{Conclusion}

In the present study, we prepared a sterol-enriched fraction from Spirogyra sp. (SPEH) and evaluated its in vitro

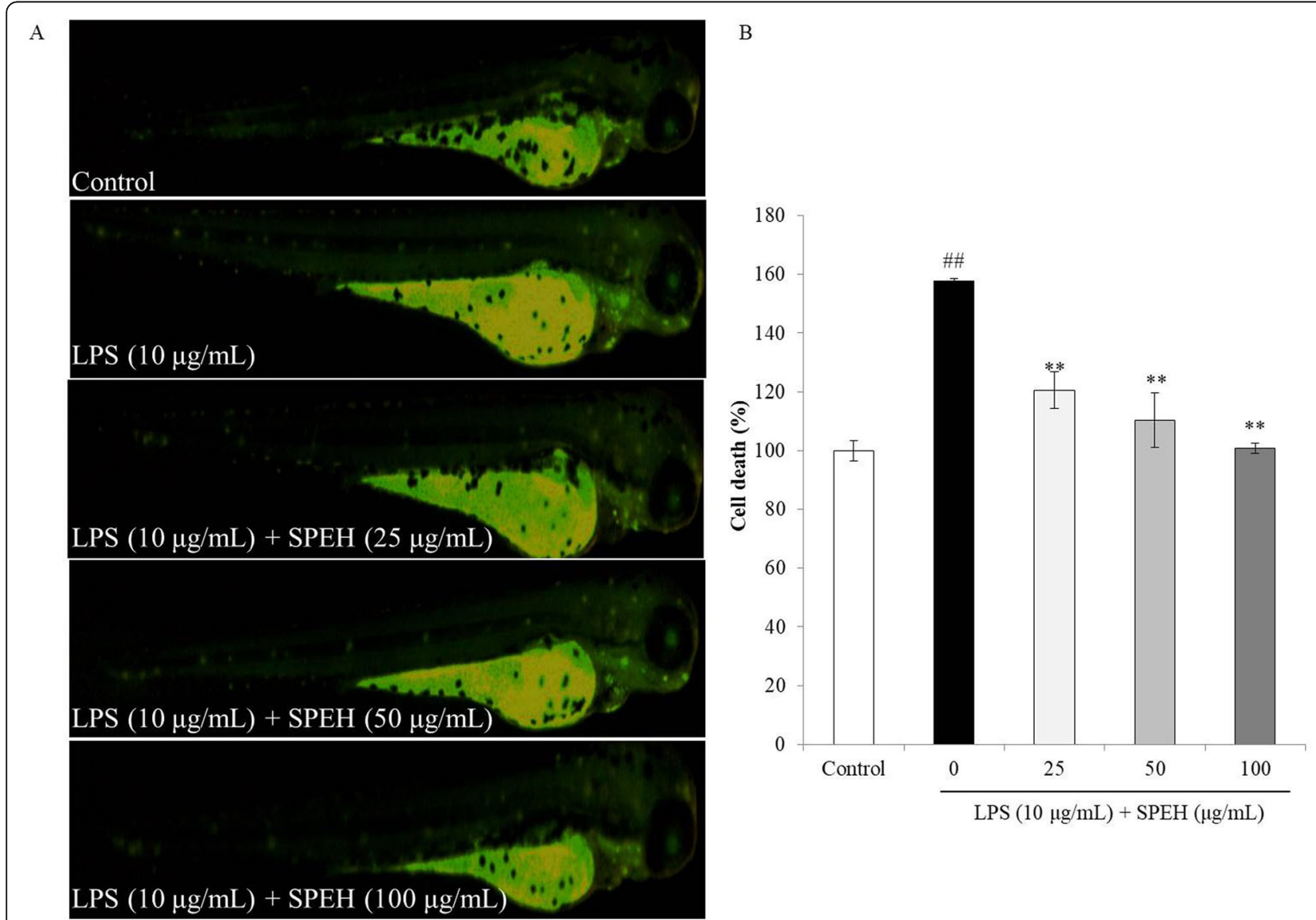

Fig. 6 The protective effect of SPEH against LPS-induced cell death in zebrafish. a Zebrafish under fluorescence microscope. $\mathbf{b}$ The levels of cell death. Cell death levels were measured using Image J software. The data were expressed as the mean \pm SE $(n=3) .{ }^{* *} p<0.01$ as compared to LPS only-treated group and ${ }^{\# \#} p<0.01$ as compared to control group 


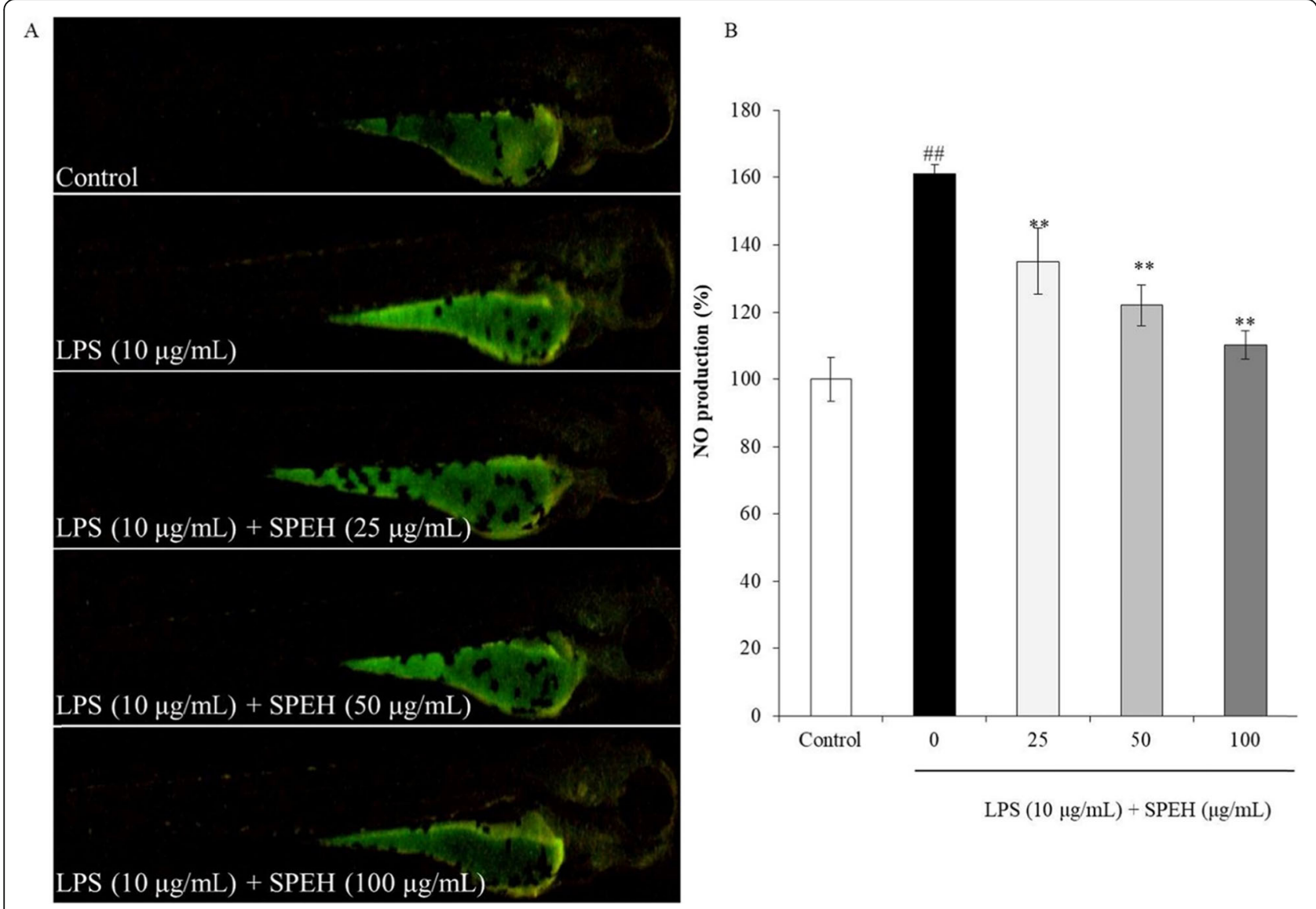

Fig. 7 The protective effect of SPEH against LPS-induced NO production in zebrafish. a Zebrafish under fluorescence microscope. $\mathbf{b}$ The levels of NO production. NO production levels were measured using ImageJ software. The data were expressed as the mean \pm SE $(n=3) .{ }^{* *} p<0.01$ as compared to LPS only-treated group and ${ }^{\# \#} p<0.01$ as compared to control group

and in vivo anti-inflammatory activities in LPSstimulated RAW 264.7 cells and zebrafish. The results indicated that SPEH possesses strong anti-inflammatory activity in both in vitro and in vivo models and has the potential to be developed as a healthcare product or a drug to treat inflammatory diseases.

\section{Acknowledgements}

Not applicable

\section{Authors' contributions}

LW, YJJ, and JIK conceived and designed the experiments. LW carried out the experiments and wrote the manuscript. YJJ and JIK corrected the manuscript. The authors read and approved the final manuscript.

\section{Funding}

This work was supported by a Research Grant of Pukyong National University (2019).

\section{Availability of data and materials}

The datasets generated and/or analyzed during the current study are available from the corresponding author on a reasonable request.

Ethics approval and consent to participate Not applicable

\section{Consent for publication}

Not applicable

\section{Competing interests}

The authors declare that they have no competing interests.

\section{Author details}

${ }^{1}$ Department of Marine Life Sciences, Jeju National University, Jeju, Self-Governing Province 63243, Republic of Korea. ${ }^{2}$ Marine Science Institute, Jeju National University, Jeju, Self-Governing Province 63333, Republic of Korea. ${ }^{3}$ Department of Food Science and Nutrition, Pukyong National University, Busan 48513, Republic of Korea.

Received: 4 August 2020 Accepted: 21 October 2020

Published online: 13 November 2020

\section{References}

Athukorala Y, Jeon YJ. Screening for angiotensin 1-converting enzyme inhibitory activity of Ecklonia cava. Prev Nutr Food Sci. 2005;10:134-9. https://doi.org/ 10.3746/jfn.2005.10.2.134.

Elbagory AM, Meyer M, Ali AH, Ameer F, Parker-Nance S, Benito MT, et al. New polyhydroxylated sterols from Palythoa tuberculosa and their apoptotic activity in cancer cells. Steroids. 2015;101:110-5. https://doi.org/10.1016/j. steroids.2015.06.009.

Fernando IPS, Kim HS, Sanjeewa KKA, Oh JY, Jeon YJ, Lee WW. Inhibition of inflammatory responses elicited by urban fine dust particles in keratinocytes and macrophages by diphlorethohydroxycarmalol isolated from a brown alga Ishige okamurae. Algae. 2017a;32:261-73. https://doi.org/10.4490/algae. 2017.32.8.14. 
Fernando IPS, Sanjeewa KKA, Le WW, Kim HS, Kim EA, Abeytunga DTU, et al. FTIR characterization and antioxidant activity of water soluble crude polysaccharides of Sri Lankan marine algae. Algae. 2017b;32:75-86. https:// doi.org/10.4490/algae.2017.32.12.1.

Firestein GS. Inhibiting inflammation in rheumatoid arthritis. N Engl J Med. 2006; 354:80. https://doi.org/10.1056/NEJMcibr054344

González Mosquera DM, Ortega YH, Kilonda A, Dehaen W, Pieters L, Apers S. Evaluation of the in vivo anti-inflammatory activity of a flavonoid glycoside from Boldoa purpurascens. Phytochem Lett. 2011;4:231-4. https://doi.org/10. 1016/j.phytol.2011.04.004.

Heo SJ, Park EJ, Lee KW, Jeon YJ. Antioxidant activities of enzymatic extracts from brown seaweeds. Bioresour Technol. 2005;96:1613-23. https://doi.org/10. 1016/j.biortech.2004.07.013.

Heo SJ, Yoon WJ, Kim KN, Ahn GN, Kang SM, Kang DH, et al. Evaluation of antiinflammatory effect of fucoxanthin isolated from brown algae in lipopolysaccharide-stimulated RAW 264.7 macrophages. Food Chem Toxicol. 2010;48:2045-51. https://doi.org/10.1016/j.fct.2010.05.003.

Jung WK, Lee DY, Kim JH, Choi IH, Park SG, Seo SK, et al. Anti-inflammatory activity of caffeic acid phenethyl ester (CAPE) extracted from Rhodiola sacra against lipopolysaccharide-induced inflammatory responses in mice. Process Biochem. 2008;43:783-7. https://doi.org/10.1016/j.procbio.2008.03.004.

Kang N, Lee JH, Lee WW, Ko JY, Kim EA, Kim JS, et al. Gallic acid isolated from Spirogyra sp. improves cardiovascular disease through a vasorelaxant and antihypertensive effect. Environ Toxicol Pharmacol. 2015;39:764-72. https:// doi.org/10.1016/j.etap.2015.02.006.

Kazłowska K, Lin HT, Chang SH, Tsai GJ. In vitro and in vivo anticancer effects of sterol fraction from red algae Porphyra dentata. Evid Based Complement Alternat Med. 2013;2013:493869. https://doi.org/10.1155/2013/493869.

Khalaf MA. Biosorption of reactive dye from textile wastewater by non-viable biomass of Aspergillus niger and Spirogyra sp. Bioresour Technol. 2008;99: 6631-4. https://doi.org/10.1016/j.biortech.2007.12.010.

Kim HH, Kim HS, Ko JY, Lee JH, Jeon YJ. A single-step isolation of useful antioxidant compounds from Ishige okamurae by using centrifugal partition chromatography. Fish Aquatic Sci. 2016;19:22. https://doi.org/10.1186/s41240 016-0023-y

Kim SF, Huri DA, Snyder SH. Inducible nitric oxide synthase binds, S-nitrosylates, and activates cyclooxygenase-2. Science. 2005;310:1966-70. https://doi.org/ 10.1126/science.1119407.

Kishi S, Uchiyama J, Baughman AM, Goto T, Lin MC, Tsai SB. The zebrafish as a vertebrate model of functional aging and very gradual senescence. Exp Gerontol. 2003;38:777-86. https://doi.org/10.1016/s0531-5565(03)00108-6.

Klegeris A, McGeer EG, McGeer PL. Therapeutic approaches to inflammation in neurodegenerative disease. Curr Opin Neurol. 2007;20:351-7. https://doi.org/ 10.1097/WCO.0b013e3280adc943.

Ko SC, Cha SH, Heo SJ, Lee SH, Kang SM, Jeon YJ. Protective effect of Ecklonia cava on UVB-induced oxidative stress: in vitro and in vivo zebrafish model. J Appl Phycol. 2011;23:697-708. https://doi.org/10.1007/s10811-010-9565-z.

Kotake-Nara E, Asai A, Nagao A. Neoxanthin and fucoxanthin induce apoptosis in PC-3 human prostate cancer cells. Cancer Lett. 2005;220:75-84. https://doi. org/10.1016/j.canlet.2004.07.048.

Ku CS, Pham TX, Park Y, Kim B, Shin MS, Kang I, et al. Edible blue-green algae reduce the production of pro-inflammatory cytokines by inhibiting NF-KB pathway in macrophages and splenocytes. Biochim Biophs Acta. 2013;1830: 2981-8. https://doi.org/10.1016/j.bbagen.2013.01.018.

Lee DM, Weinblatt ME. Rheumatoid arthritis. Lancet. 2001;358:903-11. https://doi. org/10.1016/S0140-6736(01)06075-5.

Lee JC, Hou MF, Huang HW, Chang FR, Yeh CC, Tang JY, et al. Marine algal natural products with anti-oxidative, anti-inflammatory, and anti-cancer properties. Cancer Cell Int. 2013;13:55. https://doi.org/10.1186/1475-2867-13-55.

Lee JH, Han JW, Ko JY, Lee WW, Ahn G, Kim CY, et al. Protective effect of a freshwater alga, Spirogyra sp., against lipid peroxidation in vivo zebrafish and purification of antioxidative compounds using preparative centrifugal partition chromatography. J Appl Phycol. 2016;28:181-9. https://doi.org/10. 1007/s10811-015-0548-y.

Lee SH, Ko Cl, Ahn G, You SG, Kim JS, Hue MS, et al. Molecular characteristics and anti-inflammatory activity of the fucoidan extracted from Ecklonia cava. Carbohydr Polym. 2012;89:599-606. https://doi.org/10.1016/j.carbpol.2012.03. 056.

Masresha B, Makonnen E, Debella A. In vivo anti-inflammatory activities of Ocimum suave in mice. J Ethnopharmacol. 2012;142:201-5. https://doi.org/10. 1016/j.jep.2012.04.041
Mayer AMS, Hamann MT. Marine pharmacology in 2000: marine compounds with antibacterial, anticoagulant, antifungal, anti-inflammatory, antimalarial, antiplatelet, antituberculosis, and antiviral activities; affecting the cardiovascular, immune, and nervous systems and other miscellaneous mechanisms of action. Mar Biotechnol (NY). 2003;6:37-52. https://doi.org/10. 1007/s10126-003-0007-7.

Oh JY, Fernando IPS, Jeon YJ. Potential applications of radioprotective phytochemicals from marine algae. Algae. 2016;31:403-14. https://doi.org/10. 4490/algae.2016.31.12.1.

Sanjeewa KKA, Fernando IPS, Kim SY, Kim HS, Ahn G, Jee Y, et al. In vitro and in vivo anti-inflammatory activities of high molecular weight sulfated polysaccharide; containing fucose separated from Sargassum horneri: short communication. Int J Biol Macromol. 2018;107:803-7. https://doi.org/10.1016/ j.jibiomac.2017.09.050.

Sanjeewa KKA, Fernando IPS, Samarakoon KW, Lakmal HHC, Kim EA, Kwon ON, et al. Anti-inflammatory and anti-cancer activities of sterol rich fraction of cultured marine microalga Nannochloropsis oculata. Algae. 2016;31:277-87. https://doi.org/10.4490/algae.2016.31.6.29.

Suh SS, Hong JM, Kim EJ, Jung SW, Kim SM, Kim JE, et al. Anti-inflammation and anti-cancer activity of ethanol extract of antarctic freshwater microalga, Micractinium sp. Int J Med Sci. 2018;15:929-36. https://doi.org/10.7150/ijms. 26410.

Wang L, Oh JY, Kim HS, Lee WW, Cui Y, Lee HG, et al. Protective effect of polysaccharides from Celluclast-assisted extract of Hizikia fusiforme against hydrogen peroxide-induced oxidative stress in vitro in Vero cells and in vivo in zebrafish. Int J Biol Macromol. 2018;112:483-9. https://doi.org/10.1016/j. ijbiomac.2018.01.212.

Wang L, Ryu BM, Kim WS, Kim GH, Jeon YJ. Protective effect of gallic acid derivatives from the freshwater green alga Spirogyra sp. against ultraviolet Binduced apoptosis through reactive oxygen species clearance in human keratinocytes and zebrafish. Algae. 2017;32:379-88. https://doi.org/10.4490/ algae.2017.32.11.29.

Wen ZS, Xiang XW, Jin HX, Guo XY, Liu LJ, Huang YN, et al. Composition and anti-inflammatory effect of polysaccharides from Sargassum horneri in RAW264.7 macrophages. Int J Biol Macromol. 2016;88:403-13. https://doi.org/ 10.1016/j.jijbiomac.2016.02.025

Wijesinghe WAJP, Ahn G, Lee WW, Kang MC, Kim EA, Jeon YJ. Anti-inflammatory activity of phlorotannin-rich fermented Ecklonia cava processing by-product extract in lipopolysaccharide-stimulated RAW 264.7 macrophages. J Appl Phycol. 2013;25:1207-13. https://doi.org/10.1007/s10811-012-9939-5.

Wijesinghe WAJP, Kang MC, Lee HS, Kamada T, Vairappan CS, Jeon YJ. 5ßHydroxypalisadin B isolated from red alga Laurencia snackeyi attenuates inflammatory response in lipopolysaccharide-stimulated RAW 264.7 macrophages. Algae. 2014a;29:331-41. https://doi.org/10.4490/algae.2014.29. 4.333.

Wijesinghe WAJP, Kim EA, Kang MC, Lee WW, Lee HS, Vairappan CS, et al. Assessment of anti-inflammatory effect of $5 \beta$-hydroxypalisadin B isolated from red seaweed Laurencia snackeyi in zebrafish embryo in vivo model. Environ Toxicol Pharmacol. 2014b;37:110-7. https://doi.org/10.1016/j.etap. 2013.11.006.

Xiong $\mathrm{H}$, Cheng Y, Zhang X, Zhang X. Effects of taraxasterol on iNOS and COX-2 expression in LPS-induced RAW 264.7 macrophages. J Ethnopharmacol. 2014; 155:753-7. https://doi.org/10.1016/j.jep.2014.06.023.

Xiong Q, Wilson WK, Pang J. The Liebermann-Burchard reaction: sulfonation, desaturation, and rearrangment of cholesterol in acid. Lipids. 2007:42:87-96. https://doi.org/10.1007/s11745-006-3013-5.

\section{Publisher's Note}

Springer Nature remains neutral with regard to jurisdictional claims in published maps and institutional affiliations. 